\title{
PENGARUH KEDISIPLINAN DAN KOMPENSASI TERHADAP KINERJA KARYAWAN PT BFI FINANCE,TBK CABANG PADANG
}

\author{
Ultra Ari Kusriadi, Alfian \\ STIE "KBP" PADANG \\ ultraarikuariadi@gmail.com
}

\begin{abstract}
This study aims to determine the effect of Discipline and Compensation on Employee Performance of PT BFI Finance, Tbk Padang Branch. Data collection of this study through the distribution of questionnaires to 52 respondents using a saturated sampling technique, where all members of the population in the sample. Based on the results showed that the variable discipline $T$ arithmetic of 6.815 large from $T$ table 2.009 with a significance value of 0.000 smaller than the level of significance 0.05. Whereas the $T$ compensation variable of 1.892 small than T table 2.009 with a significance value of 0.064 greater than the level of significance 0.05. can be partially inferenced the discipline has a significant effect on employee performance, while the compensation is partially no significant effect on employee performance. While the significance value of $F$ test results of 0.000 means significance smaller than 0.05. This shows that there is a positive and significant influence simultaneously or simultaneously between discipline and compensation on employee performance of PT BFI Finance, Tbk Padang Branch.
\end{abstract}

Keywords: Discipline, Compensation, and Performance

\section{PENDAHULUAN}

Dalam menghadapi era globalisasi saat ini dan dalam kondisi masyarakat sekarang, seringkali ditemukan beberapa masalah yang menyebabkan banyak perusahaan mengalami kegagalan, baik yang disebabkan oleh ketidakmampuan beradaptasi dengan kemajuan teknologi maupun yang disebabkan oleh kurang baiknya hasil kerja dari sumber daya manusia yang ada pada perusahaan tersebut.

Sumber daya manusia dalam suatu organisasi merupakan penentu yang sangat penting bagi keefektifan berjalannya kegiatan di dalam organisasi. Sumber daya manusia dalam suatu organisasi adalah orang-orang yang memberikan tenaga, bakat dan kreatifitas mereka kepada organisasi. Setiap organisasi selalu berusaha meningkatkan kinerja pegawai, dengan harapan apa yang menjadi tujuan organisasi akan tercapai. Berbagai cara akan ditempuh organisasi dalam meningkatkan kinerja pegawainya, misalnya dengan melalui disiplin dan pemberian kompensasi yang layak.

Menurut Anwar Prabu (2001:67) dalam (Minarsih, 2015) Kinerja adalah hasil kerja secara kualitas dan kuantitas yang dicapai oleh seorang pegawai dalam melaksanakan tugasnya sesuai dengan tanggung jawab yang diberikan kepadanya. 
Faktor yang mempengaruhi kinerja adalah kedisiplinan, Untuk itu pimpinan perusahaan perlu memperhatikan kedisiplinan yang dilakukan oleh seluruh karyawan pada saat bekerja. Kedisiplinan adalah kesadaran dan kesedian seseorang mentaati semua peraturan perusahaan, badan atau organisasi norma-norma sosial yang berlaku. Adanya tingkat disiplin kerja yang baik mencerminkan kredibilitas karyawan mencapai suatu hasil kerja yang optimal untuk kesuksesan perusahaan(Hasibuan S, P, 2012).

Selanjutnya Faktor-faktor lain yang mempengaruhi kinerja adalah Kompensasi, Kompensasi adalah semua pendapatan yang berbentuk uang barang langsung maupun tidak langsung yang diterima karyawan sebagai imbalan atas jasa yang di berikan oleh perusahaan. Program kompensasi mencerminkan usaha organisasi untuk mempertahankan sumber daya manusia yang dimiliki. Pemberian kompensasi yang makin baik akan mendorong karyawan untuk bekerja dengan makin baik dan produktif (Hasibuan S, P, 2012).

Penelitian ini bertujuan untuk mengetahui pengaruh Kedisiplinan dan Kompensasi terhadap kinerja karyawan PT BFI Finance, Tbk Cabang Padang.

Menurut Anwar Prabu (2001:67) dalam (Minarsih, 2015) Kinerja adalah hasil kerja secra kualitas dan kuantitas yang dicapai oleh seorang pegawai dalam melaksanakan tugasnya sesuai dengan tanggung jawab yang diberikan kepadanya.

Sedangkan menurut Suciati, Sihombing \& Kennedy (2000) kinerja adalah hasil kerja secara kualitas maupun kuantitas yang diperoleh oleh seorang pegawai didalam melaksanakan tugasnya yang sesuai dengan tanggung jawab yang diberikan kepadanya.

Menurut Suciati, Sihombing \& Kennedy (2000) mengemukakan bahwa indikator kinerja yaitu kualitas, kuantitas, pelaksanaan tugas dan tanggung jawab.

Kedisiplinan adalah suatu sikap tingkah laku dan perbuatan yang sesuai dengan peraturan dari perusahaan baik tertulis maupun tidak tertulis Hasibuan S, P, (2012)

Indikator kedisiplinan menurut Letjes, (2000) yaitu diantaranya kedisiplinan waktu, disiplinan peraturan, disiplinan tanggung jawab, konservasi

Menurut Hasibuan S, P, (2012) mengatakan bahwa kompensasi adalah semua pendapatan yang berbentuk uang, barang langsung atau tidak langsung yang diterima karyawan sebagai imbalan atas jasa yang diberikan kepada perusahaan.

Menurut Simamora, (2004) indikator kompensasi karyawan yaitu gaji, insentif, tunjangan dan fasilitas.

Hipotesis 1 Pengaruh Kedisiplinan Terhadap Kinerja Karyawan

Berdasarkan penelitian yang dilakukan oleh Harlie (2010) dalam (Mustika Utami, 2014) mengenai pengaruh disliplin kerja, motivasi dan pengembangan karir terhadap kinerja pegawai negeri sipil pada pemerintahaan negeri Kabupaten Tabalong di Tanjung Kalimantan Selatan. Dengan melakukan uji pengaruh variabel $\mathrm{X}$ yang terdiri dari Disilplin Kerja, Motivasi dan Pengembangan Karir terhadap variabel Y yaitu Kinerja. Alat uji pada penelitian ini adalah dengan menggunakan analisis regresi linier berganda. menyimpulkan hasil bahwa variabel disiplin kerja, motivasi, dan pengembangan karir memiliki pengaruh signifikan secara parsial terhadap kinerja pegawai pemerintahaan negeri Kabupaten Tabalong di Tanjung Kalimantan Selatan, dan variabel disiplin kerja memiliki kolerasi paling parsial 
tertinggi terhadap kinerja pegawai pemerintahaan negeri Kabupaten Tabalong di Tanjung Kalimantan Selatan.

H1 : Di duga Kedisiplinan berpengaruh positif dan signifikan terhadap kinerja karyawan.

Hipotesis 2 Pengaruh Kompensasi Terhadap Kinerja Karyawan

berdasarkan hasil penelitian yang di lakukan oleh Suwati (2013) dalam (Mustika Utami, 2014) mengenai pengaruh kompensasi dan motivasi kerja terhadap kinerja pada PT. Tunas Hijau Samarinda. Dengan melakukan uji pengaruh variabel $\mathrm{X}$ yang terdiri dari Kompensasi dan Motivasi terhadap variabel Y yaitu Kinerja. Alat uji pada penelitian ini adalah dengan menggunakan analisis regresi linier berganda. yaitu, menyimpulkan hasil bahwa kompensasi memberikan pengaruh yang signifikan secara parsial terhadap kinerja karyawan sedangkan motivasi kerja tidak mempunyai pengaruh yang signifikan terhadap kinerja pada PT. Tunas Hijau Samarinda

H2 : Di duga Kompensasi berpengaruh positif dan signifikan terhadap kinerja karyawan.

\section{METODE PENELITIAN}

Jenis penelitian ini menggunakan metode kuantitatif. Menurut Sugiyono (2015) data kuantitatif adalah metode penelitian yang berdasarkan pada filsafat positivisme, digunakan untuk meneliti pada populasi atau sampel tertentu, pengumpulan data mengunakan instrument penelitian. Analisis data bersifat kuantitatif/ statistik dengan tujuan untuk menguji hipotesisis yang telah ditetapkan.

Pemilihan sampel dalam penelitian ini dilakukan dengan mengunakan teknik sampling jenuh yaitu teknik penentuan sampel bila semua anggota populasi digunakan sebagai sampel (Sugiyono, 2015). Dalam hal ini sampel yang di ambil adalah keseluruhan karyawan PT BFI Finance Indonesia,Tbk cabang Padang, sehingga besarnya sampel penelitian adalah 52 orang.

Jenis data dalam penelitian ini adalah data primer dan sekunder seperti, menyebarkan kuesioner berupa pertanyaan tertulis, dan dokumentasi seperti melihat atau mencatat dokumen-dokumen perusahaan yang berkaitan dengan penelitian.

\section{PEMBAHASAN \\ Hasil Uji Validitas}

Hasil uji validitas menunjukan bahwa semua indikator yang digunakan untuk mengukur variabel-variabel yang digunakan dalam penelitian ini mempunyai nilai korelasi yang lebih besar dari 0,3. Dari hasil tersebut menunjukan bahwa semua indikator tersebut adalah valid. Hasil uji validitas ditunjukan pada Tabel di bawah ini 
Tabel 1

Hasil Uji Validitas

\begin{tabular}{|c|c|c|c|c|}
\hline Variabel & Indikator & Korelasi & $\begin{array}{c}\text { Minimal } \\
\text { Korelasi }\end{array}$ & Keterangan \\
\hline Kedisiplinan & 1 & 0.638 & 0.30 & Valid \\
& 2 & 0.691 & 0.30 & Valid \\
& 3 & 0.630 & 0.30 & Valid \\
& 4 & 0.812 & 0.30 & Valid \\
& 5 & 0.610 & 0.30 & Valid \\
\hline Kompensasis & 1 & 0.671 & 0.30 & Valid \\
& 2 & 0.812 & 0.30 & Valid \\
& 3 & 0.863 & 0.30 & Valid \\
& 4 & 0.528 & 0.30 & Valid \\
& 5 & 0.732 & 0.30 & Valid \\
\hline Kinerja & 1 & 0.650 & 0.30 & Valid \\
& 2 & 0.670 & 0.30 & Valid \\
& 3 & 0.780 & 0.30 & Valid \\
& 4 & 0.705 & 0.30 & Valid \\
& 5 & 0.718 & 0.30 & Valid \\
\hline
\end{tabular}

Sumber : Data hasil olahan kuisioner, 2018

\section{Uji Reabilitas}

Hasil uji reliabilitas menunjukan bahwa semua variabel mempunyai koefisien alpha yang lebih besar dari 0,60 sehingga dapat dikatakan semua pengukur masingmasing variabel dari kuisioner adalah reliabel. Hasil uji reliabilitas ditunjukan pada Tabel 2 Di bawah ini:

Tabel 2

Uji Reabilitas

\begin{tabular}{|l|c|c|c|}
\hline \multicolumn{1}{|c|}{ Variabel } & $\begin{array}{c}\text { Cronbach's } \\
\text { Alpha }\end{array}$ & $\begin{array}{c}\text { Standar } \\
\text { Reabilitas }\end{array}$ & Keterangan \\
\hline Kedisiplinan(X1) & 0,704 & 0,60 & Reliabel \\
\hline Kompensasi(X2) & 0,779 & 0,60 & Reliabel \\
\hline Kinerja(Y) & 0,745 & 0,60 & Reliabel \\
\hline
\end{tabular}

Sumber : Data hasil olahan kuisioner, 2018 


\section{Uji Analisis Berganda}

\section{Tabel 3}

Uji Analisis Berganda

\begin{tabular}{|c|c|c|c|c|c|c|}
\hline \multirow[b]{2}{*}{ Model } & & \multicolumn{2}{|c|}{$\begin{array}{l}\text { Unstandardized } \\
\text { Coefficients }\end{array}$} & \multirow{2}{*}{$\begin{array}{c}\text { Standardized } \\
\text { Coefficients } \\
\text { Beta } \\
\end{array}$} & \multirow[b]{2}{*}{$\mathrm{t}$} & \multirow[b]{2}{*}{ Sig. } \\
\hline & & $B$ & Std. Error & & & \\
\hline 1 & (Constant) & 1,062 & 1,409 & & .754 & .455 \\
\hline & $\begin{array}{l}\text { ke : } \\
\text { kedisiplinan }\end{array}$ & 747 & 110 & 724 & 6,815 & ,000 \\
\hline & $\begin{array}{l}\text { ko: } \\
\text { kompensasi }\end{array}$ & 192, & 102, & 201 & 1,892 & ,064 \\
\hline
\end{tabular}

Sumber : Data hasil olahan kuisioner, 2018

Berdasarkan tabel di atas dapat diperoleh model persamaan regresi sebagai berikut :

$$
\begin{aligned}
& \mathrm{Y}=\alpha+\beta 1 X 1+\beta 2 X 2 \\
& \mathrm{Y}=1,062+0,747 X 1+0,192 X 2 \\
& \text { Artinya: }
\end{aligned}
$$

1. Nilai konstanta $(\mathrm{Y})$ sebesar 1,062 : ini artinya jika variabel Kedisiplinan (X1) dan kompensasi (X2) nilainya adalah 0 (nol) atau di abaikan, maka variabel Kinerja (Y) akan berada pada angka 1,062.

2. Variabel kedisiplinan memiliki nilai koefisien regresi sebesar 0,747. Hal ini berarti jika kedisiplinan bertambah satu satuan, maka akan meningkatkan kinerja sebesar 0,747 .

3. Variabel Kompensasi memiliki nilai koefisien regresi sebesar 0,192. Hal ini berarti jika kompensasi bertambah satu satuan, maka akan meningkatkan kinerja sebesar 0,192.

4. Dari kedua variabel kedisiplinan dan kompensasi memiliki arah signifikansi positif terhadap kinerja karyawan, ini menunjukan semakin terjadi kedisiplinan dan kompensasi semakin meningkatkan kinerja karyawan.

\section{Pengujian Hipotesis}

\section{Uji F}

Dari tabel di bawah dapat di lihat bahwa F hitung sebesar 94,922 lebih besar dari $\mathrm{F}$ tabel yaitu 2,79 dengan nilai signifikansi 0,000 di mana nilai signifikansi lebih kecil dari pada taraf signifikansi $\alpha=0,05$ maka $\mathrm{H} 0$ di tolak dan H1 diterima yang berarti variabel independent kedisiplinan dan kompensasi secara silmutan (bersama-sama) memiliki pengaruh terhadap kinerja karyawan. 


\section{Tabel 4}

Uji F

ANOVA(b)

\begin{tabular}{|rl|r|r|r|r|l|}
\hline & & \multicolumn{1}{|c|}{$\begin{array}{c}\text { Sum of } \\
\text { Model }\end{array}$} & & & & \\
\hline 1 & Rquares & \multicolumn{1}{c|}{ df } & Mean Square & \multicolumn{1}{c|}{$\mathrm{F}$} & \multicolumn{1}{c|}{ Sig. } \\
\hline & on & 283,943 & 2 & 141,971 & 94,922 &, $000(\mathrm{a})$ \\
& Residual & 73,288 & 49 & 1,496 & & \\
& Total & 357,231 & 51 & & & \\
\hline
\end{tabular}

Sumber : Data hasil olahan kuisioner, 2018

\section{Uji T}

Berdasarkan tabel uji parsial di bawah dapat diketahui bahwa variabel kedisiplinan $\mathrm{T}$ hitung sebesar 6,815 > T tabel 2,009 dan tingkat signifikansi $\mathrm{T}$ lebih kecil dari 0,05 (sig. $0,000<0,05$ ) maka $\mathrm{H}_{\mathrm{a}}$ di terima. Sedangkan variabel kompensasi $\mathrm{T}$ hitung sebesar 1,892 $<\mathrm{T}$ tabel 2,009 dan tingkat signifikansi $\mathrm{T}$ lebih besar dari 0,05 (sig. 0,064>0,05) maka $\mathrm{H}_{0}$ diterima. dapat di simpulkan secara parsial kedisiplinan mempunyai pengaruh yang signifikan terhadap kinerja karyawan, sedangkan kompensasi secara parsial tidak berpengaruh signifikan terhadap kinerja karyawan.

\section{Tabel 5}

Uji T

Coefficients(a)

\begin{tabular}{|c|c|c|c|c|c|c|}
\hline \multirow[b]{2}{*}{ Model } & & \multicolumn{2}{|c|}{$\begin{array}{l}\text { Unstandardized } \\
\text { Coefficients }\end{array}$} & \multirow{2}{*}{\begin{tabular}{|c}
$\begin{array}{c}\text { Standardized } \\
\text { Coefficients }\end{array}$ \\
Beta \\
\end{tabular}} & \multirow[b]{2}{*}{$t$} & \multirow[b]{2}{*}{ Sig. } \\
\hline & & $B$ & $\begin{array}{l}\text { Std. } \\
\text { Error }\end{array}$ & & & \\
\hline 1 & (Constant) & 1,062 & 1,409 & & 754 & ,455 \\
\hline & $\begin{array}{l}\text { ke : } \\
\text { kedisiplinan }\end{array}$ & ,747 & 110 & 724 & 6,815 & ,000 \\
\hline & $\begin{array}{l}\text { ko: } \\
\text { kompensasi }\end{array}$ & , 192 & 102 & 201 & 1,892 & ,064 \\
\hline
\end{tabular}

Sumber : Data hasil olahan kuisioner, 2018

\section{Uji R}

Berdasarkan tabel di bawah dapat diketahui nilai Adjusted R Square sebesar 0,786. Dengan kata lain semua variabel indpenden (Kedisiplinan dan kompensasi) mampu menjelaskan variabel dependen (kinerja karyawan) 
sebesar $78 \%$, sedangkan sisanya $22 \%$ di pengaruhi oleh faktor-faktor lain yang tidak di ajukan dalam penelitian ini

\section{Tabel 6}

Hasil Uji Determinasi

Model Summary

\begin{tabular}{|c|c|c|c|c|}
\hline Model & $\mathrm{R}$ & R Square & $\begin{array}{l}\text { Adjusted R } \\
\text { Square }\end{array}$ & $\begin{array}{l}\text { Std. Error of the } \\
\text { Estimate }\end{array}$ \\
\hline \multicolumn{5}{|l|}{1} \\
\hline & ,892(a) & ,795 & ,786 & 1,22298 \\
\hline
\end{tabular}

Sumber : Data hasil olahan kuisioner, 2018

Berdasarkan kepada analilsis hasil pengujian hipotesis yang telah dilakukan dapat di ajukan pembahasan sebagai berikut:

1. Pengaruh kedisiplinan terhadap Kinerja Karyawan

Berdasarkan hasil pengujian H1 di temukan bahwa kedisiplinan berpengaruh positif terhadap kinerja karyawan PT BFI Finance, Tbk Cabang Padang Hal ini di lihat dari T hitung 6,815 dengan nilai signifikansi 0.000 yang berarti kecil dari tingkat signifikan (0.05). hal ini sama dengan penelitian terdahulu yang di teliti oleh Harlie (2010) yang mengemukakan kedisiplinan berpengaruh signifikan dan positif terhadap kinerja karyawan.

2. Pengaruh Kompensasi terhadap Kinerja Karyawan

Berdasarkan hasil pengujian $\mathrm{H} 2$ di temukan bahwa Kompensasi tidak berpengaruh terhadap kinerja karyawan PT BFI Finance,Tbk Cabang Padang hal ini di lihat dari $\mathrm{T}$ hitung 1,892 dengan nilai signifikansi sebesar 0.064 Lebih besar dari tingkat signifikansi (0.05). hal ini berbeda dengan penelitian terdahulu yang di teliti oleh Suwati (2013) yang mengemukakan Kompensasi berpengaruh positif dan signifikan terhadap kinerja karyawan. Hasil pengujian secara stastistik menunjukan bahwa variabel Kompensasi tidak berpengaruh terhadap kinerja karyawan PT BFI Finance,Tbk Cabang Padang, melalui pengujian hipotesis dapat di ketahui bahwa pada variabel kompensasi masingmasing item pertanyaan di jawab sangat setuju dan setuju dengan persentase yang cukup besar, sehinnga nilai signifikansi lebih besar dari tingkat signifikansi. Hasil penelitian di lapangan menunjukan bahwa pemberian kompensasi tidak dapat meningkatkan kinerja karyawan PT BFI Finance,Tbk Cabang Padang. Meskipun demikian, perhatian perusahaan terhadap pengaturan kompensasi secara rasional dan adil sangat di perlukan. Bila karyawan memandang pemberian kompensasi tidak memadai presatai kerja maupun tingkat kinerja karyawan akan cenderung menurun. 


\section{SIMPULAN}

Dari hasil pengujian hipotesis yang telah dilakukan maka dapat disimpulkan sebagai berikut :

1. Kedisiplinan berpengaruh positif dan signifikan terhadap kinerja karyawan PT BFI Finance cabang Padang

2. Kompensasi tidak berpengaruh positif dan signifikan terhadap kinerja karyawan PT BFI Finance cabang Padang.

3. Berdasarkan hasil penelitian diperoleh $78 \%$ Kinerja karyawan pada PT BFI Finance,Tbk yang dapat dijelaskan oleh variable Kedisiplinan dan Kompensasi sedangkan sisanya sebesar $22 \%$ dijelaskan oleh variabel variabel yang tidak diteliti dalam penelitian ini.

\section{UCAPAN TERIMAKASIH}

Ucapan terima kasih untuk bapak Febryandhie Ananda, SE, M.Si selaku ketua Sekolah Tinggi Ekonomi Keuangan Perbankan dan Pembangunan (STIE"KBP" Padang) beserta Staf Pimpinan, Karyawan dan Karyawati di STIE"KBP” Padang. Bapak Alfian, SE, MM selaku pembimbing dalam penulisan skripsi ini. Bapak dan Ibu Dosen STIE"KBP” Padang yang telah membantu penulis selama menuntut ilmu yang bermanfaat kepada penulis selama perkuliahan. Teman-teman dan pihak-pihak lain yang membantu penulis dalam menyelesaikan skripsi ini yang tidak dapat penulis sebutkan satu persatu namanya.

\section{DAFTAR PUSTAKA}

anggy, henly dkk. (2016). pengaruh budaya organisasi,disiplin kerja, dan lingkungan kerja terhadap kinerja karyawan pada PT PLN(Persero)Kantor Wilayah Suluttenggo.

Arfindy, parerung dkk. (2014). Disiplin, Kompensasi dan Pengembangan Karir Pengaruhnya Terhadap Kinerja Pegawai Pada Badan Lingkungan Hidup Provinsi Sulawesi Utara, 2(4).

Arikunto, S. (2002). Prosedur Penelitian Suatu Pendekatan Praktek, PT. Rineka Cipta, Jakarta.

Elizabeth, satriowati dkk. (2016). Pengaruh Gaya Kepemimpinan Transformasional, Kompensasi Dan Komunikasi Terhadap Kinerja Karyawan Dengan Kepuasan Kerja Sebagai Variabel Mediasi Pada Laundry Elephant King.

Dona, E. (2016). Pengaruh Perencanaan, Prosedur Dan Pengawasan dan Komitmen Organisasi Dalam Pelaksanaan Anggaran Terhadap Kinerja Pegawai Dinas Pekerjaan Umum Kota Pariaman. Jurnal Riset Manajemen dan Akuntansi (Jurmak), 23-35.

Dona, E. (2018). Analisis Motivasi Kerja Ditinjau Dari Lingkungan Kerja Kasus Karyawan LBPP Lia Payakumbuh. Jurnal KBP. 
fudin, zainal abidin. (2013). Pengaruh Disiplin Terhadap Kinerja Karyawan Pada PT. Rekatama Putra Gegana Bandung.

Ghozali, I. (2011). Aplikasi Analisis Multivariate dengan Program IBM SPSS 20 (6th ed.). Semarang: Universitas Diponegoro.

Hamlan, D. (2015). Pengaruh kompetensi, disiplin dan kompensasi terhadap kinerja pegawai badan pemberdayaan perempuan dan keluarga berencana daerah provinsi sulawesi tengah, 84-94.

Hasibuan S, P, M. (2012). Manajemen Sumber Daya Manusia. Edisi Revisi. PT Bumi Aksara. Jakarta.

Letjes. (2000). Jaminan sosial tenaga kerja. Jakarat: Erlangga.

Lubis, A. Y. O., \& Susanti, F. (2019). Pengaruh Gaya Kepemimpinan Dan Kompensasi Terhadap Prestasi Kerja Karyawan (Studi pada PT Japfa Comfeed Indonesia (JCI) Tbk Devisi Fam 1. https://doi.org/10.31227/osf.io/7tbrg

Mayliza, R. (2019). Pengaruh Gaya Kepemimpinan Dan Disiplin Kerja Terhadap Kinerja Karyawan Dengan Motivasi Kerja Sebagai Variabel Intervening Pada PT. Semen Padang. https://doi.org/10.17605/OSF.IO/FYPQ9.

Mayliza, R. (2019). Pengaruh Konflik Dan Kejenuhan Terhadap Kepuasan Kerja Karyawan PT. PLN (Persero) Sektor Pembangkitan Dan Pengendalian Pembangkitan Ombilin. https://doi.org/10.17605/OSF.IO/DQZ3K

Mayliza, R. (2019). Kontribusi Sistem Penghargaan Dan Lingkungan Kerja Terhadap Efektifitas Kerja Pegawai Pada Kantor Dinas Pendidikan Kota Padang. https://doi.org/10.17605/OSF.IO/VWZH3

Mayliza, R. (2019). Pengaruh Gaya Kepemimpinan Dan Disiplin Kerja Terhadap Kinerja Pegawai, Dengan Motivasi Kerja Sebagai Variabel Intervening (Studi Pada Dinas Pendidikan Kabupaten Tanah Datar). https://doi.org/10.17605/OSF.IO/JGPDN

Minarsih, M. M. (2015). Pengaruh Kompensasi , Motivasi Kerja, Lingkungan kerja dan disiplin terhadap Kinerja Karyawan pada CV Koperasi Puri Kencana Taxi Semarang, 1-23.

Mustika Utami, F. (2014). Pengaruh Kompensasi dan di Siplin Kerja Terhadap Kinerja karyawan, 14.

Nardo, R. Evanita, Syahrizal, S. (2018). Pengaruh Kepemimpinan Transformasional, Dan Lingkungan Kerja Non Fisik Terhadap Perilaku Inovatif. JEBI (Jurnal Ekonomi dan Bisnis Islam) 3 (2), 209-215

Nardo, R. Evanita, Syahrizal, S. (2019). The Effect of Transformational Leadership and Non Physical Work Environment on Innovative Behavior with Work Motivation as a Mediation For Employees of Tour And Travel Companies In West Sumatera. 2nd Padang International Conference on Education, Economics, Business and Accounting (PICEEBA-2 2018)

Susriyanti, S. Nardo, R. (2019). Pengaruh Fungsi Komunikasi Dan Kepuasan Kerja Karyawan Terhadap Pemberian Pelayanan Nasabah PT. BPR LPN Talawi Sakato. Jurnal Administrasi Sosial dan Humaniora 3 (2), 97-111.

Putra, RY. Marlius, D. (2019). Pengaruh Pendidikan, Pengalaman Kerja dan Etos Kerja Terhadap Kinerja Pegawai Di KPN Batur. Academic Conference For Management 2. 
Rahmizal, M. (2018). Pengaruh Pendapatan, Pendidikan, Kesehatan, Modal Sosial Dan Religiusitas Terhadap Kebahagiaan Individu Di Indonesia. Universitas Gadjah Mada

Ridho, M., \& Susanti, F. (2019). Pengaruh Stres Kerja Dan Motivasi Kerja Terhadap Kepuasan Kerja Pada Karyawan Bank Mandiri Syariah Cabang Padang. https://doi.org/10.31227/osf.io/pa2cg

Rivai. (2004). Manajemen Sumber Daya Manusia Untuk Perusahaan, Jakarta: PT. Rajagrafindo Persada. Jakarta: Murai Kencana.

Sastrohadiwiroyo. (2005). kedisiplinan kerja. bandung: alfabeta andy.

Simamora. (2004). Manajemen Sumber Daya Manusia Edisi III. Jakarta: STIE YKPN Sperling, 2007. "Psychology: Made Simple", London, The Publisher W. H. Allen \& Co. Ltd. Supranto, 2009. Statistik Teori dan Aplikasi, Edisi ketujuh Jilid 2. Jakarta: Penerbit Erlangga.

Suciati, Sihombing \& Kennedy, 2016. (2000). Management Journal. Princeton, NJ, 9220(1), 63-79.

Sugiyono. (2015). Metode Penelitian dan Pengembangan, Penerbit Alfabeta Bandung. Yogyakarta. 